\title{
THE INFLUENCE OF COMPENSATION AND LEADERSHIP ON EMPLOYEE TURNOVER
}

\author{
Didin Hikmah Perkasa ${ }^{1 *}$, Ferryal Abadi ${ }^{1}$ \\ ${ }^{1}$ Institute of Technology and Business, Kalbis \\ *didin.hikmah@kalbis.ac.id
}

\begin{abstract}
It is necessary to do this research because of the high employee turnover in the last several years. The aim of this research is to analyze the influence of compensation and leadership on employee turnover. The analysis unit of this research is the employees who have not worked in a company anymore. The population consists of 76 employees with 44 samples obtained from the use of slovin sampling technique and questionnaire as the research instrument. The method of quantitative analysis is used in this research with the tool of Multilinear Regression analysis, followed by determination analysis ( $R$ Square), partial hypothetical test (t test) and simultaneous hypothetical test (F test), alpha (error tolerance) five percents. Before spreading questionnaire, validity and reliability tests are carried out until all the questionnaires are said to be valid and reliable. To fulfill the criteria and requirements of Multilinear Regression analysis, classical assumption analysis such as normality test, homogenity test, multicollinearity test, heterocedasticity test are done first. The tool aid for data processing is SPSS version 21.0. The result of this research is that the variable of compensation in partial has a significant influence on employee turnover, whereas the variable of leadership insignificantly influences employee turnover.
\end{abstract}

Keywords: compensation, leadership, turnover

\section{INTRODUCTION}

Human Resources are the most important element of a company because they are the motor of the company's operation. Not only try to find quality human resources, every company in generalwill try to retain the human resources who are considered as competent. Prawironegoro and Utari (2016) state that the task of a leader is to develop, drive, direct and order his members to act for reaching the goal. One of the requirements an employee should fulfill is having technical skills in accordance with the job requirements that have been predetermined by the company. In addition to mastering technical skills, an employee should also has good personalities to be able to lead others since not all employees with above-average technical skills are able to lead others. The better the leadershipis implemented, the better the company he leads. Unfortunately, the leadership styleimplemented by a leader may be accepted or rejected by the employees. Those who feel uncomfortable will make decision to adapt the condition by learning how to accept the leadershipimplemented or just make decision to leave the company and work for another company.

Providing balanced compensationwith regard to the work load faced by the employees can enhance the motivation to work so that they can work more productively. Beside having rights to receive compensation, every employee also has rights to resign from a companyby following the predetermined procedures. This makes employee turnoverin a companyinevitable. High employee turnovercauses additional cost in the recruitment process and additional time necessary for new employee's on the job training. The problem is companies' high employee turnover where in one month there are one to two employee resignations from a same position. The turnover is dominated by the staff with tenure less than one year. This indicates some dominant causesthat make employees tend to move to another company. This is also supported by the previous research done by Pangke (2011), which states that the reasons for employee resignation are the matters of wage surety and welfare, working environment, personality and mentality, domicile/boarding house, and family problem.

The research done by Wahyuni, et. al (2014) concludes that the most dominant factors influencing construction companyemployee'sturnover intention are of external factors such as salary, incentive and 
supervisor's attitude. Paripurna, Supartha, Subudi (2015), Agustini, Tenti (2014), Amany, Jovi (2016) in his [their] journal studies[study] the influence of leadershipand job satisfaction on turnover intention and its impact on the employee's performance of PT Agung Automall Kuta. The research result concludes that leadershipdoes not significantly influence employee's turnover intention. Sukron (2011), Sudita (2015)in their journal study the influence of leadership style, motivation, compensation, and job satisfaction onemployee's turnover intention of PT Garudafood Putra Putri Jaya Pati. From the research it can be concluded that leadership style, motivation, compensation, and job satisfaction influence employee's turnover intention.

\section{Problem Statement}

Based on the background, the author formulates the problems faced in research as follows:

1. Does compensation significantly influence employee turnover?

2. Does leadershipsignificantly influence employee turnover?

\section{THEORITICAL FRAMEWORK}

\section{Employee turnover}

According to Mobley (2010) quoted by Tussoleha (2016), turnover is the resignation of an individual from an organization. Whereas according to Price (2012) quoted by Tussoleha (2016), turnover is the movement of an individualacross the membership limitation of the current company. Noe (2011) divides turnover into two types, namely:

a) Voluntary Turnover, that is the employee's decision to leave the companyvoluntarily. It is usually caused by the low attractiveness of the current job and the availability of alternative jobs.

b) Involuntary Turnover, that is a dismissalreflecting the employer's decision to terminate the employment and it is beyond the employee's control.

Based on this opinion, the author concludes that employee turnoveris when an employee decides to quit working in a companyfor some reasons, whether to work in another companyor for other reasons.According to Tussoleha (2016), there are some factors causing turnover:

a) Internal factors from the individual

b) Internal driving factors from the individual

c) Internal factorsfrom the company

d) External factorsout of the company

\section{Compensation}

Sastrohadiworyo (2015) as quoted by Sinambela (2016) says that compensationis the reward given by an organization to the work forces since they have contributed their energy and thoughts for the sake of advancing the organization and achieving the predetermined goals.

According to Kasmir (2016), compensationis the reward provided by a companyfor its employees both financial and non-financial. Whereas Rivai and Sagala (2011) as quoted by Sinambela (2016) define compensationas something received by an employee as the exchange of their contribution to the company. Based on the abovementioned opinions, the author concludes that compensationhas several elements, namely:

a) Reward

b) Employee's contribution

According to Santoso and Masman (2016), based on its nature, compensationis classified into two:

a) Direct Compensation. It is the compensationreceived directly and periodically, such as basic salary, holiday allowance, cash benefit, bonus and incentives.

b) Indirect Compensation. It is the component received indirectly and not routinely. Usually what will be received "later" or "if" something happens to the employee, among others are transport facilities, parking facilities, health facilities.

\section{Leadership}

According to Handoko (2012), leadershipis the ability to influence (persuade) other people to achieve the goals enthusiastically. In another word, leadershipis a human factor which binds a group of 
people by motivating them to achieve the goal. According to Heidjrachman and Husna (2011), leadership styleis any behaviour pattern which is designed to integrate the organizational goal and individual goal in order to achieve a certain goal. Based on those opinions, the researcher concludes that leadershipis an effort to influence other people to achieve a goal together.According to Siagian (2015), there are several types of leadership;

a) Autocratic type

b) Paternalistic type

c) Charismatic type

d) Democratic type.

\section{Framework}

Based on the theoretical background supported by previous researches, the framework of this research is as follows:

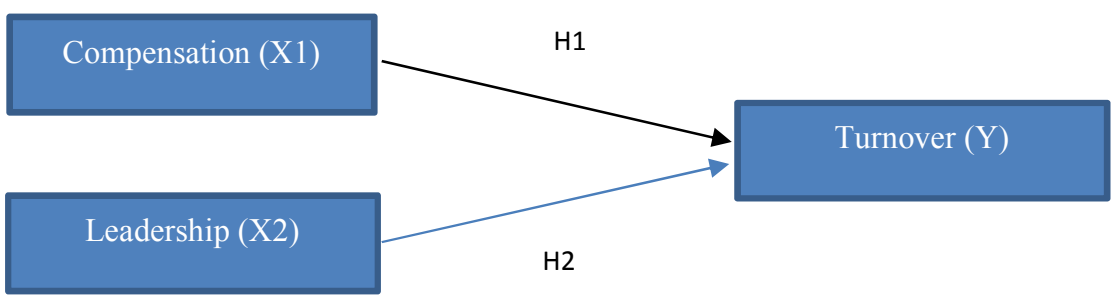

Figure 1. Framework

\section{Hypotheses}

H1: $\quad$ There is an influence of compensationon employee turnover

H2: $\quad$ There is an influence of leadership styleon employee turnover

\section{METHOD}

The object of this research is an IT companyin Jakarta, the analysis unit is the employees of an IT companyin Jakarta. This research uses the method of surveyto study the respondents' perception. The population of this research is 76employees who have resigned and the sampling uses slovin method because not all the employees will be interviewed, and it gets 44 respondents as the sample. The sampling technique uses simple random sampling technique. Theinstrument used in this research is questionnaire.The data consists of secondary and primary data. Before collecting data through respondents, there have been validity test and reliability test on the questionnaires, until all the questionnairesare considered as valid and reliable.

The analysis uses quantitative analysis method with the analysis toolof Multilinear Regression, at the level of error 5\% (0.05), and the tool aid for data processing is SPSS 21 application. Multilinear regression analysis only can be done if it has fulfilled the criteria and requirements of classic assumption such as normality test, multicollinearity test, and heterocedasticity test. The multilinear regression equation is $\mathrm{Y}=\mathrm{a}+\mathrm{b} 1 . \mathrm{X} 1+\mathrm{b} 2 \mathrm{X} 2+\mathrm{e}$. Where $\mathrm{Y}=$ turnover; $\mathrm{a}=$ Constant; $\mathrm{b} 1=$ Regression coefficient of $\mathrm{X} 1$; b2 = Regression coefficient of X2; X1=compensation; $\mathrm{X} 2=$ leadership; $\mathrm{e}=$ error/other factors.

Multilinear regression analysis is followed by Determination ( $\mathrm{R}$ Square) analysis to show how independentvariables $(\mathrm{X} 1 \& \mathrm{X} 2)$ can explain and give contribution to dependent variable (Y). Then, it continues with partial hypothetical test ( $\mathrm{t}$ test), simultaneous hypothetical test ( $\mathrm{F}$ test) and interdimension correlation analysis. The criteria for hypothetical test are as follows:

1) If $t$ statistic $>t$ table, it means the independentvariables $(X 1 \&, X 2)$ partially influence the dependentvariable $(\mathrm{Y})$. If alpha (significance level) $<0.05$, it means the independent variables $(\mathrm{X} 1 \&$ $\mathrm{X} 2$ ) partially and significantly influence the dependent variable $(\mathrm{Y})$; and 
2) If $F$ statistic $>F$ table, it means the independent variables (X1 \& X2) simultaneously influence the dependent variableand if the alpha (significance level) $<0.05$, it means the independent variables(X1\& X2) simultaneously and significantly influence the dependent variable (Y).

\section{RESULT AND DISCUSSION}

\section{Results of Validity Test}

The result of calculation for the indicator of compensationvariable is bigger than $r$ table $=0.30$, so it can be concluded that the indicator of compensationvariable is said to be valid.The result of calculation for the indicator of leadershipvariable is bigger than $r$ table $=0.30$, so it can be concluded that the indicator of leadership variable is said to be valid. The result of calculation for the indicator of turnover variable is bigger than $\mathrm{r}$ table $=0.30$, so it can be concluded that the indicator of turnovervariable is said to be valid.

The reliability test using SPSS program finds that the coefficients of Cronbach's Alpha for the variables of compensation, leadershipand turnoverhave been above 0.6. Thus, it can be concluded that the tree variables are reliable.

\section{Classic Assumption Test}

\section{Normality Test}

With normality test using Kolgomorov-Smirnovtest, it can be found whether the data being used is normally distributed or not. If Asymp. Sig (2-tailed) > 0.05, then the data is normally distributed.

The decisions whether the data variable is normally distributed or not are as follows:

1. The Asymp. Sig (2-tailed) value of Compensationvariable is $0.818>0.05$, then the data is normally distributed.

2. The Asymp. Sig (2-tailed) value of Leadership Stylevariable is $0.807>0.05$, then the data is normally distributed.

3. The Asymp. Sig (2-tailed) value of Turnover variable is $0.124>0.05$, then the data is normally distributed.

Table 1. Result of Normality Test

\begin{tabular}{llrrr}
\hline & & X1 & \multicolumn{1}{c}{ X2 } & \multicolumn{1}{c}{ Y } \\
\hline $\mathrm{N}$ & & 44 & 44 & 44 \\
Normal Parameters $^{\mathrm{a}}$ & Mean & 3.836 & 3.659 & 3.761 \\
& Std. Dev & .6929 & .7660 & .7738 \\
Most Extreme Differences & Absolute & .095 & .096 & .178 \\
& Positive & .095 & .085 & .178 \\
& Negative & -.089 & -.096 & -.117 \\
Kolmogorov-Smirnov Z & & .633 & .640 & 1.179 \\
Asymp. Sig. (2-tailed) & & .818 & .807 & .124 \\
\hline
\end{tabular}

\section{Multicollinearity Test}

Multicollinearity test is used to know the existence of linear relationship among independent variables in the regression model. The prerequisite that should be fulfilled in the regression model is that there is no multicollinearity. The symptoms of multicollinearity, among others, can be seen from the value of Inflation Factor (VIF)in the regression model. The bases for decision making are:

1. $\mathrm{VIF}>10=$ there is a multicollinearityamong independent variables

2. $\mathrm{VIF}<10=$ there is no multicollinearityamong independent variables 
Table 2. Result of Multicollinearity Test

\begin{tabular}{ccccccc}
\hline & & \multicolumn{2}{c}{$\begin{array}{c}\text { Unstandardized } \\
\text { Coefficients }\end{array}$} & $\begin{array}{c}\text { Standardized } \\
\text { Coefficients }\end{array}$ & \multicolumn{2}{c}{$\begin{array}{c}\text { Collinearity } \\
\text { Statistics }\end{array}$} \\
\cline { 2 - 7 } Model & B & Std. Error & Beta & Tolerance & VIF \\
1 & (Constant) & .457 & .433 & & & \\
X1 & .708 & .202 & .634 & .300 & 3.335 \\
X2 & .161 & .183 & .159 & .300 & 3.335 \\
\hline \multicolumn{4}{c}{ Source: Data processing byIBM SPSS }
\end{tabular}

The test results in Table 2 show that the value of all independent variables have tolerance bigger than 0.1 and the VIF is less than 10. It means there is no symptoms of multicollinearity in the regression model because the figure of both VIFsis 3.335.

\section{Heterocedasticity test}

Heterocedasticity test in this research is done by seeing the scatterplot between the residual data that has been standardized (SDRESID) and the predictive result of dependent variable that has been standardized (ZPRED). The problem of heterocedasticity in the residualdata.

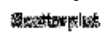

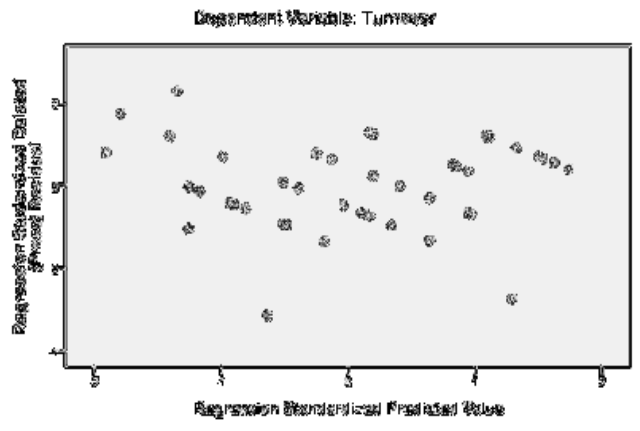

Figure 2. Result of Heterocedasticity Test

From the scatterplotshown in the figure above, it can be seen that the data does not make a certain pattern and the datadots do not concentrate only above or below the figure 0 but they spread above and under it.Thus, it can be concluded that there is no problem of heterocedasticity in the residualdata.

\section{Multilinear Regression Test}

Multilinear regression test is to know the description about the influence of two or more $\mathrm{X}$ variables as independent variableswith $\mathrm{Y}$ as dependent variable. In this research, multilinear regression analysis is done to know the coefficient of regression or the influence on the dependent variable, that is employee turnover (Y), while the independent variables are compensation(X1) and leadership (X2). This research uses multilinear regression analysis because it has more than one independent variable. 
Table 3. Results of Multilinear Regression Analysis

\begin{tabular}{|c|c|c|c|c|c|c|}
\hline & & \multicolumn{2}{|c|}{$\begin{array}{c}\text { Unstandardized } \\
\text { Coefficients }\end{array}$} & \multirow{2}{*}{$\begin{array}{c}\text { Standardized } \\
\text { Coefficients } \\
\text { Beta } \\
\end{array}$} & \multirow[b]{2}{*}{$\mathrm{t}$} & \multirow[b]{2}{*}{ Sig. } \\
\hline \multicolumn{2}{|c|}{ Model } & $\mathrm{B}$ & Std. Error & & & \\
\hline \multirow[t]{4}{*}{1} & (Constant) & .457 & .433 & & 1.058 & .296 \\
\hline & $\mathrm{X} 1$ & .708 & .202 & .634 & 3.497 & .001 \\
\hline & $\mathrm{X} 2$ & .161 & .183 & .159 & .877 & .386 \\
\hline & a. Depend & Varia & le: Turnover & & & \\
\hline
\end{tabular}

Source: Data processing by IBM SPSS

Based on Table 3, it can be obtained the formula of multilinear regression equation for the influence of independent variables (compensationand leadership) on the dependent variable (employee turnover) as follows:

$$
\begin{aligned}
& \mathrm{Y}=\mathrm{a}+\mathrm{b} 1 \mathrm{x} 1+\mathrm{b} 2 \times 2+\mathrm{e} \\
& \mathrm{Y}=0.457+0.708 \mathrm{X} 1+0.161 \mathrm{X} 2+\mathrm{e}
\end{aligned}
$$

The multilinear regression equation can be interpreted as follows:

a. The constant 0.457 is the intersection of regression line with the $\mathrm{Y}$ axis showing the employee turnoverof PT IT Group Indonesia when the independent variables, namely compensation (X1) and leadership(X2), isequal to zero (0).

b. The variable of compensation (X1) has positive coefficient of regression, meaning that if the variable of compensation (X1) increases one unit then the employee turnoverin PT IT Group Indonesia will increase equal to the coefficient of regression, that is 0.708 , with the assumption that the other independent variable is constant.

c. The variable of leadership (X2) has positive coefficient of regression, meaning that if the variable of leadership (X2) increases one unit then the employee turnover di PT IT Group Indonesia will increase equal to the coefficient of regression, that is 0.161 with the assumption that the other independent variable is constant.

\section{Hypothetical Tests}

\section{Coefficientof Determination Test (R2)}

Coefficient of determination test is done to measure how far the regression model can explain the dependent variable. R Squareis used to measure the regression line's goodness of fits. The results of this test can be seen from the value of Adjusted R Squarein the following table:

\begin{tabular}{|c|c|c|c|c|}
\hline Model & $\mathrm{R}$ & R Square & $\begin{array}{l}\text { Adjusted R } \\
\text { Square }\end{array}$ & $\begin{array}{l}\text { Std. Error of } \\
\text { the Estimate }\end{array}$ \\
\hline 1 & $.772^{\mathrm{a}}$ & .596 & .576 & .5037 \\
\hline \multicolumn{5}{|c|}{$\begin{array}{l}\text { a. Predictors: (Constant), Leadership, Compensation } \\
\text { b. Dependent Variable: Turnover }\end{array}$} \\
\hline \multicolumn{5}{|c|}{ Source: Data processing by IBM SPSS } \\
\hline
\end{tabular}

Table 4. Results of Coefficient of Determination Test

In Table 4. the coefficientof determinantor the value of Adjusted R square $\left(R^{2}\right)$ is 0.576 or $57.6 \%$ which means the contribution of employee turnover can be explained by the variables of compensationand leadership. And the rest of $42.4 \%$ is explained by other variables not studied in this research.

\section{Simultaneous Test (F Test)}

F test is the test model used to know whether the result of regression analysis is significant or not, or in another word, the predicted is appropriate or not. The significance used here is 0.5.

The criteria of test are: 
a. If the value of sig $>0.5$ then $\mathrm{Ha}$ is rejected, meaning that the independent variables compensation and leadership simultaneously do not have significant influence on dependent variableemployee turnover.

b. If the value of sig $<0.5$ then $\mathrm{Ha}$ is accepted, meaning that the independent variables compensation and leadership simultaneously have significant influence on dependent variableemployee turnover.

Table 5. Results of Simultaneous Test

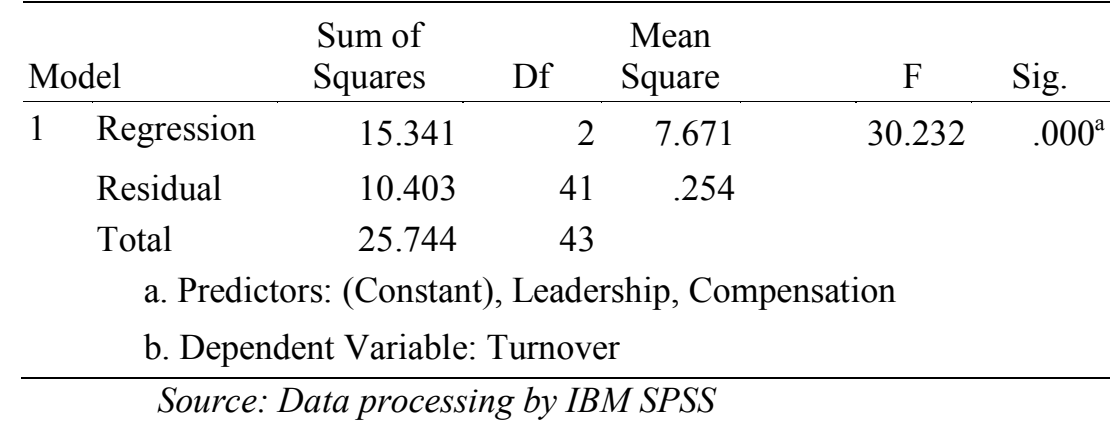

Based on the table above, the significance value of $\mathrm{F}$ is 30.232 with probability of sig $0.000<$ 0.05. It can be concluded that the independent variables, namely compensationand leadership,simultaneously influence the dependent variable, namely employee turnover.

\section{Partial Test (t Test)}

$T$ test is used to know whether the independent variables in partial have real influence or not on the dependent variable. The significance used here is 0.05 . If the probability $<0.05$ then Ho is rejected and $\mathrm{Ha}$ is accepted, meaning that the independent variables (compensationand leadership) in partial have significant influence on the dependent variable (employee turnover).

From the two independent variables appliedto the regression model inthe table above:

a. Compensation $\left(X_{1}\right)$ has the value of significance $(0.001<0.05)$, then Ho is rejected, meaning that in partial, compensation $\left(X_{1}\right)$ positively and significantly influences the variable of employee turnover $(\mathrm{Y})$.

b. Leadership $\left(X_{2}\right)$ has the value of significance $(0.386>0.05)$, then Ho is accepted, meaning that in partial, leadership $\left(X_{2}\right)$ does not significantly influence the variable of employee turnover(Y).

\section{RESULT AND DISCUSSION}

\section{The Influence of Compensationon Employee turnover}

From $t$ test, the coefficientto know the influence of compensation (X1) on employee turnover (Y) it is found sig as $0.001<0.05$, then in partial there is a significant influence of compensationon employee turnover. This is in line with the research done by Elisa Putri Kumalasari (2016), entitled Pengaruh Kompensasi dan Beban Kerja terhadap Turnover Karyawan pada PT JVC Electronic Indonesia. The research shows that compensationinfluences employee turnover.

This is also stated by Indri Dwi Astriani (2015) in her thesis entitled Pengaruh Kompensasi dan Kepuasan Kerja terhadap Turnover Karyawan Perjanjian Kerja Waktu Tertentu PT Danischa Farma.The research concludes that compensationand job satisfaction influence employee turnover.

Another research showing similar result is the one carried out by Roni Ardiyansyah Sukron (2011) in his journal which is entitled PengaruhGaya Kepemimpinan, Motivasi, Kompensasi,dan Kepuasan Kerja Terhadap Keinginan Berpindah Karyawan PT Garudafood Putra Putri Jaya Pati. The research concludes that leadership style, motivation, compensation, and job satisfaction influence employee's intention to leave the company.

The same thing happens to the research object where the amount of compensation,both directly and indirectly, positively influences employee turnover. This shows that employee turnoverwill keep increasing although the amount of compensationincreases. This result contradicts the theory saying that compensationshould negatively influence employee turnoverwhere the higher the 
compensationprovided the lower the degree of employee turnover will be. The difference happens due to the possibility that other indicatorsare not involved in the research.

\section{The Influence of Leadershipon Employee Turnover}

From the $t$ test, the coefficientfor knowing the influence of compensation (X1) on employee turnover $(\mathrm{Y})$ results in sig $0.386>0.05$. Then, in partial there is no significant influence of leadershipon employee turnover. This is in line with the research carried out by Yudo Astiko (2012), Analisis Pengaruh Leadershipdan Keadilan Kompensasi terhadap Kepuasan Kerja Serta Dampaknya pada Turnover Intention Tenaga Keperawatan (Studi Di Rumah Sakit Panti Wilasa Citarum Semarang). The research shows that leadershipdoes not influence employee turnover.

This is also stated by I Gede Diatmika Paripurna, I Wayan Gede Supartha, Made Subudi (2015) who study the influence of leadershipand job satisfaction on the turnover intention and its impact on the employee performance of PT Agung Automall Kuta. The research concludes that leadershipdoes not significantly influence employee's turnover intention.

Another research showing the similar result is the one carried out by Tesha Jovi Amany (2016) who studies the influence of work stress, satisfaction with salary and leadershipon the auditor staff's turnover intentions in Public Accountant Office. Theresearch concludes that leadership styledoes not influence employees to leave the company. The same thing happens to the research object where leadershipdoes not influence the degree of turnover because the leadershipimplemented in the company is still acceptable for the employees.

\section{CONCLUSION}

\section{a. Conclusions}

After having made analysis on the research results concerning the influence of compensationand leadership style, conclusions can be made as follows:

a. The result of $t$ statistictest for the variable ofcompensation (X1), it is found that the variable of compensationpartially influences employee turnover.

b. The result of $t$ statistictest for the variable ofleadership(X2), it is found that the variable of leadershippartiallydoes not influence employee turnover.

\section{b. Suggestions}

Based on the conclusions above, in this article the author give suggestions as follows:

1) For the company

a. Based on the result of questionnaire, the companyis expected to be able to provide compensationin accordance with each emeployee's competence as well as bonus and incentive based on the performance.

b. Based on the result of questionnaire, the management is expected to more involve the employees and listen to their opinions in making decisions.

2) For the following researchers

This research is expected to be able to contribute information concerning the influence of compensationand leadership styleon employee turnover. It is also expected to be beneficial in the development of Human Resource Management science, especially in relation with the influence of compensationand leadership styleon employee turnoverin the future.

\section{REFERENCES}

Amany, T. J., Nasir, A., \& Idrus, R. (2016). Pengaruh Stres Kerja, Kepuasan Tingkat Gaji Dan Kepemimpinan Terhadap Turnover Intentions Staff Auditor Di Kantor Akuntan Publik (Studi Pada Kap Di Jakarta Dan Bandung). Jurnal Online Mahasiswa Fakultas Ekonomi Universitas Riau, 3(1), 2387-2398. 
Hani, H. (2012). Manajemen personalia dan sumber daya manusia edisi ketujuh.

Hedrajrahcman., \& Suad, H. (2011). Manajemen Personalia. Yogyakarta: BPFE UGM.

International Labour Organization. (2013). Manajemen Sumber Daya Manusia untuk Kerjasama dan Usaha yang Sukses. Jakarta. International Labour Office.

Kasmir. (2016). Manajemen Sumber Daya Manusia (Teori dan Praktek). Cetakan Pertama. Depok: Rajagrafindo Persada

Paripurna, I. G. D. (2017). Pengaruh Kepemimpinan dan Kepuasan Kerja Terhadap Turnover Intention Serta Dampaknya Terhadap Kinerja Karyawan pada PT Agung Automall Kuta.Tesis Universitas Udayana. Bali

Prawironegoro, D., \& Utari, D. (2016). Manajemen SDM Abad 21. Edisi Revisi. Jakarta: Mitra Wacana Media

Santoso, Y., \& Masman, R. (2016). A Practical Guidance Executive Compensation Management. Cetakan Pertama. Jakarta: Elex Media Komputindo

Sondang, P. S. (2015). Teori dan Praktek Kepemimpinan. Cetakan 6. Jakarta: Rineka Cipta

Sudita, I. N. (2015). Pengaruh Kepuasan Gaji, Kepuasan Kerja, dan Komitmen Organisasional terhadap Turnover Intention (Studi Kasus pada Bidan Praktek Swasta di Kabupaten Sleman). Jurnal Fakultas Ekonomi Universitas Janabadra Vol 6 (1). Yogyakarta

Sukron., \& Roni, A. (2011). Pengaruh Gaya Kepemimpinan, Motivasi, Kompensasi, Dan Kepuasan Kerja Terhadap Keinginan Berpindah Karyawan PT Garudafood Putra Putri Jaya Pati.Jurnal Fakultas Ekonomi dan Bisnis Universitas Dian Nuswantoro. Semarang

Tussoleha, R., \& Zahra. (2016). Siapa Harus Pergi Siapa Harus Tinggal Strategi Mencegah Turnover Karyawan Gen Y. Cetakan Pertama. Jakarta: Pusat Studi Sumber Daya Manusia

Wahyuni, et. al. (2014). Analisis Faktor-Faktor yang Mempengaruhi Turnover Intention (Keinginan Berpindah) Karyawan pada Perusahan Jasa Konstruksi. Jurnal Fakultas Teknik Universitas Brawijaya Vol 8 (2). Malang 